\title{
Everyday politics of austerity: Infrastructure and vulnerability in times of crisis
}

DOI:

$10.1177 / 2399654419831293$

\section{Document Version}

Accepted author manuscript

Link to publication record in Manchester Research Explorer

\section{Citation for published version (APA):}

Petrova, S., \& Prodromidou, A. (2019). Everyday politics of austerity: Infrastructure and vulnerability in times of crisis. Environment and Planning C: Politics and Space. https://doi.org/10.1177/2399654419831293

\section{Published in:}

Environment and Planning C: Politics and Space

\section{Citing this paper}

Please note that where the full-text provided on Manchester Research Explorer is the Author Accepted Manuscript or Proof version this may differ from the final Published version. If citing, it is advised that you check and use the publisher's definitive version.

\section{General rights}

Copyright and moral rights for the publications made accessible in the Research Explorer are retained by the authors and/or other copyright owners and it is a condition of accessing publications that users recognise and abide by the legal requirements associated with these rights.

\section{Takedown policy}

If you believe that this document breaches copyright please refer to the University of Manchester's Takedown Procedures [http://man.ac.uk/04Y6Bo] or contact uml.scholarlycommunications@manchester.ac.uk providing relevant details, so we can investigate your claim.

\section{OPEN ACCESS}




\title{
Everyday politics of austerity: infrastructure and vulnerability in times of crisis
}

\author{
Abstract
}

Growing numbers of households in Greece are unable to secure adequate levels of energy services in the home - a condition generally known as energy poverty. This situation can largely be attributed to the imposition of an austerity regime following the post-2008 debt crisis. We scrutinize the everyday experiences of, and resistance to, austerity among the 'new energy poor' - an emergent socio-demographic group whose vulnerability is contingent upon decreasing incomes, high prices, new taxation and inadequate socio-technical infrastructures. Having undertaken ethnographic research with 25 households living in and around the Northern Greek city of Thessaloniki, we draw on theoretical insights from the domains of informal household practices and environmentality frameworks to highlight the manner in which the austerity regime simultaneously renders households vulnerable and governable. The geographies of the new energy poor include a variety of spatial settings - in urban and peri-urban locations alike - that are constitutive of multiple material sites while being dependent upon them. This points to the existence of an infrastructurally-embedded everyday landscape of austerity that amalgamates the state policies, corporate interests, household practices and material pathways through which energy is produced and consumed.

Keywords: infrastructure, energy poverty, austerity, everyday geographies, Greece. 


\section{Introduction}

Austerity governance has become the new face of neoliberalism. Understandings of the phenomenon are multifaceted. In socio-cultural geography, austerity has been depicted as a 'condition' (Hall, 2015) that results from cuts in public budgets and requires 'doing more with less' (Dąbrowski, 2015, page 73). Newman (2017) has identified three distinctive aspects of austerity: 'policy', 'ideology' and 'governmentality'. Analyses of austerity as 'policy' and as a ‘condition' are similar, and focus on the effects of cuts and production of disadvantages and vulnerabilities (ibid). Theorizing austerity as 'ideology' embeds the tendency and struggle for the legitimization of austerity as a hegemonic ruling idea (Newman, 2017, page 25). The governmentality of austerity focuses on technologies of governance associated with efforts to shrink the state via technocratic processes of devolution (ibid). In this regard, austerity can be understood as a constitutive part of broader and longer processes of neoliberal precarization, underpinned by the replacement of permanent job opportunities with temporary employment contracts offering minimal social security, or the decreased provision of health insurance, paid holidays, and pensions (Lorey, 2015). While austerity research has focused predominantly on scrutinizing large scale structural change (Bristow and Healy, 2015; Peck, 2012), more recent contributions have focused on the everyday strategies and tactics developed by people to overcome the consequences of austerity regimes (Hall, 2015; Vaiou, 2014). A research lacuna, however, remains with regard to the individual and domestic intimate encounters and contestations of austerity-related 'new (or nouveau) poor'. 
Greece has become the epitome of austerity, and in the Greek context, Kaika (2012, page 423) has explained that the emergent category of 'new poor' is constituted by people who 'belonged, until recently, to the middle classes, but were [removed from] these ranks as they lost their jobs, took massive cuts in their salaries or pensions, or had their homes repossessed'. The new poor cut across traditional class boundaries, by including people of different genders and ages, as well as diverse ethnic and educational backgrounds. As Kaika (2012, page 423) elaborates, such individuals are not 'migrants, junkies, alcoholics or homeless' and they do not belong to the urban 'other' or 'subaltern', but they are perceived by many as 'our poor' (ibid: 425): neighbours and relatives who have been rapidly impoverished as a result of austerity. In Greece, austerity has been orchestrated by the 'Quartet' of international decision makers (European Commission, European Central Bank and the International Monetary Fund and the European Stability Mechanism).

The rise of energy poverty - commonly defined as the inability of a household to secure a socially- and materially-necessitated level of energy services in the home (Bouzarovski and Petrova, 2015) - is a further characteristic of the austerity regime in Greece. This poorly understood and politically neglected phenomenon has both intensified and been predicated upon antecedent problems, such as thinly-insulated and inadequately heated homes, and built, institutional or ownership arrangements that do not allow households to improve the efficiency of the housing stock or switch towards more affordable fuels (Katsoulakos, 2011; Santamouris et al., 2014). At the same time, energy prices in the country have increased in order to allow for the privatization of energy utilities - one of the principal declared aims of the austerity regime. 
Building upon the aforementioned contribution by Kaika (2012), this paper develops the notion of the 'new energy poor': people who become unable to secure adequate domestic energy services due to the economic crisis and austerity regime, as well as path-dependent infrastructural and policy settings. In highlighting the distinctive features of this group, the paper aims to contribute to wider debates on the creation of subjects (Rose, 2002) and everyday mundane resistance, and the relationship between energy poverty and austerity more specifically. I thus interrogate the quotidian experiences of energy deprivation and strategies instigated by the 'new energy poor' to overcome and resist the lack of energy services across a variety of urban and periurban sites.

Following the introduction, the first part of the paper provides a critical analysis of the relationship between austerity and energy more generally, while outlining some of the key conceptual tools that we have employed. The second section focuses on the rise of domestic energy deprivation and the new poor in post-crisis Greece. We then explore the everyday infrastructural dimensions of energy poverty, so as to unpack the tactics and strategies developed to overcome the enforced inability to meet basic household needs, and the socio-political making of 'energy subjects' in this context. Then follows a section that scrutinizes the performativity of everyday resistance with regard to energy poverty. The conclusion critically highlights the significance of our research findings within the context of wider relationships between the everyday articulation of infrastructure, on the one hand, and the production of capitalism, on the other. 


\section{Energy demand in the age of austerity}

There is evidence to suggest that the imposition of an austerity regime has significantly affected the affordability of domestic energy services in Greece (Papada and Kaliampakos, 2016). But information about the relationship between energy and austerity can be gleaned only indirectly, due to the lack of specific research on the energy poverty-inducing nature of austerity (Arampatzi, 2017). Individuals' inability to pay energy bills fully and on time has largely stemmed from the reduction of household incomes. Policies of strict fiscal discipline and severe cuts on public spending have been enforced in order to restore 'budgetary integrity' and the functioning of the market. Wages have been reduced by as much as 40 per cent since the start of the crisis, with the unemployment increasing from 13 per cent in 2010 to 28 per cent in 2013 (Mavroudeas, 2014). In addition, the informalization of the labour market has augmented the number of people who are only able to get casual or unpaid jobs (ibid).

Greece has also seen increases of state levies on all commercial energy products, as well as the introduction of an additional property tax on top of electricity bills (Dagoumas and Kitsios, 2014). These measures have led to a marked decrease in overall residential electricity consumption (ibid). A constitutional challenge submitted to the Greek Supreme Court (Ioakimidis et al., 2014) did not prevent the government from incorporating the property tax in electricity bills. Yet social workers have been given the discretionary power to decide which non-paying households would be disconnected from the grid, on the basis that 'vulnerable' groups would be protected from having their power supply cut. The definition of 'vulnerable' in this context has 
been highly restrictive and precise, with targets for disconnections being set by the state (Ioakimidis et al., 2014). The consequence has been what Greece's dominant power utility - the Public Power Corporation (PPC) - considers to be increased levels of 'electricity theft'. They have reported that this is costing the company about 170 million euros in lost income each year, and that there is a debt of 2.6 billion euros in unpaid bills (Makris, 2017). The Hellenic Electricity Distribution Network Operator (HEDNO), responsible for the control of electricity meters, has reported that verified cases of theft climbed to 10,600 in 2016, up from 8,880 in 2013 and 4,470 in 2012 (ibid). In the first ten months of 2017, PPC cut the power supply of 240,000 consumers; 159,000 of them got their electricity back after making a debt payment settlement with the PPC or paying their debts. Still, over 80000 may still be without electricity (Keep Talking Greece, 2017).

The austerity regime has also hindered the political willingness and capacity to democratize the energy system in Greece. SYRIZA - the leading leftist party in power - has developed an energy program that acknowledges the need to address climate change by transforming the national energy system from fossil to renewable energy. The strategy also includes a clear desire to ensure public control of energy companies by re-nationalizing or stopping the privatization of energy utilities (Sweeney, 2015). The program promises a new social energy paradigm, which is based on decentralized production and provision of energy. But SYRIZA's socioenvironmental turn in the energy sector has been derailed by austerity agreements and imposed demands for the neoliberalization of the Greek economy. The party's nowdeposed energy minister Panagiotis Lafazanis contested the privatization of the energy sector, arguing that it would reinforce extant social inequalities in the country 
while creating 'painful economic and social complications' (Michalopoulos, 2015). Nevertheless, the sale of the Independent Power Transmission Operator grid operator (ADMIE; currently a 100 per cent subsidiary of the incumbent PPC) was expected to be launched during 2016, in compliance with the terms of the international bailout.

Even if empirical work has quantified the effect on austerity on energy demand in Greece (and beyond, see Bouzarovski and Tirado Herrero, 2015), missing from this debate is a focus on the manner in which austerity measures have produced unevenly distributed socio-spatial vulnerabilities in the context of antecedent geographies of infrastructural service inequality (Hadjimichalis, 2011; Vaiou, 2014). Despite the argument that the effects of austerity may be more obvious in bigger cities such as Athens and Thessaloniki (Dagoumas and Kitsios, 2014), Katsoulakos and Kaliampakos (2014) have highlighted the need to explore energy poverty issues in rural and mountainous areas where levels of energy deprivation may be higher die to harsher climates.

The neoliberal rationale is that austerity is the only response to market conditions (Brown, 2016). Austerity uses various discourses of fear and control to create a governable class of people (Peck, 2012). Of relevance in this context is the notion of environmentality - a paradigm based on the Foucauldian concept of governmentality (Foucault, 1991) - which describes the different ways in which the state exerts sovereign environmental power on its subjects by imposing environmental rules and norms (Singh, 2013). Environmentality-related discourses and policies have sought to regulate people's conduct in ways that reshape social relations and actions (Boyd et al., 2014a). In the case of Italy, for example, Pollio (2016, page 514) highlights that 
'smart city' policies have 'become one of the foundational political technologies for the implementation of austerity measures' by providing a discursive lexicon for the promotion of cost-containment measures and 'pro-innovation' public expenditures across a variety of decision-making sites and institutions. In Greece, the period since 2009 has seen a 30 per cent increase in the mass concentration of PM 2.5 particles and a up to five-fold increase in the concentration of wood smoke tracers within large urban areas mostly due to the increased use of fuelwood for residential space heating (Saffari et al., 2013). The situation became especially dramatic in the winter of 2012, when big cities such as Athens and Thessaloniki were covered in smog for days. As a result, the Ministry of Health and the Ministry of Environment, Energy and Climate Change announced 'Long-term Action Plans to Cope with Air Pollution by Particulate Matter' according to which the use of fireplaces and wood-stoves would be banned if the concentration of particulate matter were to exceed 150 micrograms per cubic meter of air. The Plan was heavily criticized for being vague in terms of locating the exact sites where biomass burning would be forbidden, in addition to providing insufficient frameworks for measuring, monitoring and regulating the individual use of fuelwood. Also, it was not made clear at the time what kinds of alternative solutions would be provided. The state's intervention heightened environmentality discourses (Agrawal, 2005; Boyd et al., 2014a) in the context of austerity policies. The new regulation has led to the further precarization of already vulnerable households, while creating additional socio-spatial inequalities.

While recognizing the challenges of linking the intimate geographies of households (Valentine, 2008) with austerity, understanding the geographies of people's dealings with austerity is important for the development of wider progressive politics (Jupp, 
2016). This is where the lack of research on the links between energy, environmentality and austerity becomes particularly apparent (Alejos and Paz, 2013), especially in the context of residential energy use. There is also a need to explore the effects of austerity policies beyond cities, since there is evidence to suggest that rural or suburban areas may be vulnerable in distinctive ways (Katsoulakos, 2011). Even more, it remains unclear whether and how austerity has affected the everyday rhythms and synchronicities of residential energy use (Walker, 2014), creating new temporal patterns embedded in the social world. How politics and space come together to produce diverse geographies of contestation also necessitates further exploration - especially in light of findings that 'sustainable energy transitions and pathways ... are mediated by unique place and context-specific conditions that exert influence on the mobilisation of resources, governance capabilities and actornetworks' (De Laurentis et al., 2016).

\section{Methods}

In order to identify the extent and experiences of energy poverty at the household level under austerity, 25 household ethnographies were undertaken in inner city of Thessaloniki as well as peri-urban areas in its wider region; with peri-urban here being understood as comprising both suburban and exurban districts, which often fuse together due to the specific history and geography of urban sprawl in Greece (Leontidou et al., 2007). Completing 25 ethnographies allowed for encompassing the widest possible range of household situations and residential circumstances. 
Thessaloniki is the second largest city in the country ${ }^{1}$, strategically situated in the Thermaikos Gulf in Northern Greece. The city is called the co-capital' of Greece based on the strength of its economy, industry and commercial sectors.

The decision to focus the study on Thessaloniki stemmed from the specific characteristics and research opportunities afforded by this city. First, Thessaloniki has a rich and long history of citizen struggles over urban infrastructure, which has received significantly less research attention in comparison to Athens. To date, scholarship on such contestations has mainly focused on large scale development projects (Karaliotas, 2017), with domestic contestations around energy remaining relatively marginalized. Second, in spatial terms, the region of Thessaloniki is characterized by a continuous socio-spatial topography that includes peri-urban areas in addition to a large urban nucleus. While the central part of the city has been built based on the Greek 'antiparochi' system (for more details on this model, please see Maloutas and Karadimitriou, 2001) which produced the distinctive look of city areas with multi-storey apartment buildings, peri-urban areas have been developed in a more spontaneous manner - often not in line with the urban plans. Such areas thus include a more diverse combination of housing types, sizes and qualities - revealing multiple infrastructural entanglements and everyday struggles. Third, and with regards to energy, there has been strong evidence of the rapid expansion of the 'grey' economy and alternative share economies in the city during recent years (Sideri, 2016); some of these have been linked to the provision of energy services. Adding to this is the fact that households in Thessaloniki need both energy for heating and

\footnotetext{
${ }^{1}$ According to the 2011 Census, the city region has approximately 1 million inhabitants.
} 
cooling due to the local climate - providing fertile ground for studying energy poverty in relation to multiple environmental conditions, austerity and everyday life.

The choice of target households was made via snowballing through the authors' existing professional and personal contacts in Thessaloniki. The aim was to ensure a diverse range of household-level socio-demographic, housing and energy use circumstances (see Table 1, noting that names have been changed in order to protect the interviewees' identity). In total, 13 and 12 of the surveyed household lived, respectively, in the inner-city of Thessaloniki and three surrounding peri-urban districts. Based on socio-economic indicators - particularly per capita income - all of these households would have been considered 'middle-class' before the economic crisis. Based on Mouzelis (1979) and Poulantzas (1977), this paper's understanding of the Greek middle class includes both the traditional petite bourgeois (such as small businesspeople, tradespeople, and craftworkers) and the so-called new petite bourgeois class (various types of professionals such as doctors, lawyers, engineers, pharmacists and other). Their energy consumption was monitored over two weeks: one during the summer (i.e. the space cooling season) in 2013, and another during the winter (the space heating season) in 2014. All households were asked to keep energy diaries, by recording their energy use and everyday life patterns during the two monitoring weeks. In designing the diaries we relied on approaches and techniques developed in the otherwise limited literature on the method (Petrova, 2017b).

In order to gather information about the households' domestic energy, economic, housing and social conditions, as well as their housing careers and household biographies, each household was interviewed twice: once at the beginning of the 
research and once at the end. In total, 55 adults were included in the study. Some of the households included in the research had children (17 in total), which were not interviewed or included in any way for ethical reasons.

\section{(INSERT TABLE 1 HERE)}

Following the argument that the physical location of interviews affects the course of discussions (Elwood and Martin, 2000), interviews were undertaken in the participants' homes so as to ensure that all household members were as comfortable as possible. The interviews were designed in a manner that allowed all adult household members to be involved in the research. Similar approaches have been used in the context of 'family studies' (Valentine, 1999). While caution was exercised about group dynamics in this context, it was also recognized that such a data collection method would provide a 'more efficient use of resources and ... a means of adding valuable insight to the interpretation of a social or behavioral event' (Frey and Fontana, 1991, page 175).

The interviews were semi-structured, with three types of questions being asked, on $i$ ) the everyday patterns of energy use; ii) the effects of the crisis on economic and psychological well-being; and iii) attitudes and practices relating to the relationship between austerity and residential energy use. These general themes were amended where appropriate and necessary in order to capture the specificity of every household. Inductive analysis was used to interpret the evidence: it allows for patterns, themes and categories to emerge from the data rather than being imposed $a$ priori, in order to increase the scope and room for interpretation (Baxter and Eyles, 
1997). The analysis also included documentary evidence (policy and media reports as

well as legal and policy documents); its results have been presented in summary form in the text that follows, with quotes and vignettes from selected households being provided as illustrations of wider points.

\section{Locating and unpacking the 'new energy poor'}

There is little doubt that austerity has increased overall energy poverty rates in Greece. A 400 household survey undertaken in 2015 indicated the presence of domestic energy deprivation symptoms among a staggering 58 per cent of the sample, with 75 per cent of the surveyed households reporting that they had to trade off other essentials in favour of energy (Papada and Kaliampakos, 2016). A study undertaken between 2011 and 2013 revealed that average- and low-income households either reduced or completely stopped the use of heating systems (Santamouris and Kolokotsa, 2015). The interviews highlighted the diverse occupational and economic backgrounds of households suffering from domestic energy deprivation, thus supporting Kaika's (2012) argument that the new poor constitute a new social formation that includes people from different social classes. Olga, a recently unemployed banker, stated that:

'All the people who I know have the same problems regarding energy poverty. What is striking is that they come from various social strata. I have friends who are civil servants, others who have their own businesses, doctors, chemists, we all have the same problem. The difference is that they are affected to a different degree' (H22, summer interview). 
The Greek state has developed a number of financial mechanisms to improve the affordability of energy services in the homes of vulnerable people. Special social electricity tariffs have been provided for residential consumers, including a discount of up to 42 per cent on annual electricity consumption levels below $5000 \mathrm{kWh}$ (Dagoumas and Kitsios, 2014). Heating oil - a widespread fuel in Greece - has also been subsidized, even if increased taxation has driven up the price of this carrier by more than 50 per cent since 2011 (ibid). Heating oil subsidies have been based on technical and financial criteria, taking into consideration climate-induced variations in energy demand. But the lack of common standards in the setting of heating oil tariffs has led to significant variation in the final prices associated with this energy source, with many areas being further disadvantaged by inconsistencies in the determination of climate zones and the official regulation's underestimation of consumption levels (see Katsoulakos and Kaliampakos, 2014). Another problem has been the centralized supply of oil in apartment buildings that is based on a collective decision of all residents. This means that even relatively better-off households that could hypothetically afford more oil may not be able to get it if the remaining households cannot pay for their share.

It was frequently highlighted in the research that the social support system favours households that use small amounts of electricity - primarily poorer pensioners. It does little to help families with young children. Maximos and Olga's family had energy needs that exceeded state-mandated criteria: 
'We tried to get an energy discount from the state because we have low incomes. But in order to achieve that we had to consume $500 \mathrm{kwh}$ per month. It is impossible for us to use electricity up to $500 \mathrm{kwh}$. I cook every day, use the washing machine frequently. This is how our household operates' (H22, winter interview).

Some of the households reported that they had become eligible to receive benefits after the austerity-induced measures. The lack of prior experience with the benefits system meant that they were both puzzled by and ashamed of the application system. Elpida thought that the existing system of benefits is 'a joke':

'Interviewer: Are you up to date with the benefits that the government offers for heating?

Elpida: Yes. But it does not concern me because it is only for oil. Interviewer: So you wouldn't even consider it? Elpida: No because it is a joke! They give you 30 euros every time you buy 1 ton of oil. Go into all the bureaucracy for what?' (H3, summer interview).

There is evidence to suggest the existence of a complex set of austerity-induced relationships at the nexus of energy poverty and the built environment. Based on data from 50 households in inner-city Athens, Paravantis and Santamouris (2014) found that indoor wintertime temperatures vary between $9.9{ }^{\circ} \mathrm{C}$ and $28.6{ }^{\circ} \mathrm{C}$, with averages between $15.9{ }^{\circ} \mathrm{C}$ and $20.7{ }^{\circ} \mathrm{C}$. These levels are significantly lower than the benchmark values recommended by the World Health Organization (World Health Organization Regional Office for Europe, 2007). To some extent, such policy deficiencies have 
been offset by a government-instigated home energy savings campaign, aimed at raising awareness about residential energy efficiency and consumption. This effort has also included subsidies for energy efficiency improvements of the housing stock, targeted at low-income groups while covering up to 70 per cent of eligible costs (Katsoulakos and Kaliampakos, 2014). But complex bureaucratic procedures have combined with the rigid definition of vulnerable households (Pye et al., 2015) to hamper the effectiveness and reach of such schemes.

The existence of such constraints means that people try to operate with the means they have available, and in ways that are shaped by forces outside their immediate control (Simone, 2016). Our research revealed that spatial variations in energy poverty patterns exist in addition to the development of alternative energy end-use strategies that have been developed in response to strict austerity politics. It became evident that energy poverty is experienced and articulated differently by urban and peri-urban dwellers, pointing to the need for integrative thinking and analysis of energy poverty beyond the urban-rural divide. The lack of gas infrastructure in periurban areas has created additional pressure on households to find alternative sources of energy, often requiring improvised alterations of the built structure. Fuelwood was the most common heating method chosen by interviewed households living at the edges of the city, mainly owing to the smaller size of the buildings and the ease of installing wood-burning stoves. According to Knight (2014), the increased use of fuelwood should not come as a surprise: every crisis embeds memories of previous difficult periods, and the solutions to current problems usually involve techniques and practices used in the past. Wood-burning stoves are a well-known energy device in Greece, principally providing heat and cooking services in rural areas. The return of 
this 'archaic' system of space heating to urban areas has usually been accompanied by the reliance on more modern appliances such as air conditioners. Still, many interviewed people were not feeling comfortably warm:

'With the wood burner and the air-conditioner, without using the radiator, only part of the house is heated. The bedroom and the bathroom are still cold and this bothers me. The rooms that are not heated have a problem with mould, despite the fact that the house is insulated' (Antonia, H1, winter interview).

The households that relied on pellets or fuelwood also reported high levels of smoke in the home, leading to additional costs for re-decorating the rooms where the stoves were located. At the same time, many households in the inner-city were not able to install such appliances at all - they require the construction of new external chimneys, which cannot be done without planning permission. Such households' only remaining option was to use less electricity. For some, this meant reducing the consumption of particular energy services, such as heating, cooling and showering. Hera and Gregorios explained the everyday adjustments associated with these tactics:

'We changed the way we use energy nowadays. I use a timer when I heat the water in the winter, and when there is a really sunny day we all take baths in a row' (Hera, H11, winter interview).

It has been shown that the antiparochi model has created 'vertical social differentiation' in inner-city areas in Greece that could leave potentially socioeconomically vulnerable households locked in apartments on lower floors (Maloutas 
and Karadimitriou, 2001) which tend to be more prone to humidity, lack of daylight and lower levels of energy efficiency. Adonia and Alekos (H4, summer interview) parents of two small children, who live in one such apartment - had decreased their energy demand in both spatial and temporal terms: the bedroom was not heated at all, and the overall amount of daily heating hours was drastically cut. The consequences of the lack of adequate temperatures in the home were multiple, with the presence of mould being mentioned most often. The situation in the home of Adonia and Alekos became especially dramatic when mould affected the health of their children:

'So we had a very serious problem because there was a foul smell of humidity and mould. And it was not just the walls, it was also our stuff that smelled in the drawers, in the wardrobe, behind the furniture, underneath the bed. Humidity and mould even destroyed our bed mattress' (H4, summer interview).

The prolonged health effects of inadequate heating meant that people mostly talked about the forthcoming winter during the summer interviews. This goes counter to anecdotal expectations that winter heating should not be a problem in Greece's Mediterranean climate (Healy, 2004). As Petra noted:

'The first thing that we talk about after we say 'how are you?' with our friends is 'how are we going to get warm?' (H17, summer interview).

To summarize: the documentary evidence and interviews in Thessaloniki revealed the complex social and spatial patterns that influence the emergence of Greece's new 
energy poor. The factors leading to this group's exclusion extend beyond the determinants of income poverty to encompass a wide variety of socio-demographic, institutional and built environments that render some households more vulnerable by virtue of their demographic circumstances, housing conditions, and relationship to the state. Such findings point to the need for moving beyond the triad energy prices, incomes and energy efficiency within which energy poverty has been traditionally conceptualized (Bouzarovski, 2014; Petrova et al., 2013). The material deprivation brought about by energy poverty has left a deep psychological imprint on affected households, highlighting a pathway through which austerity comes to shape individual and group identities.

\section{The making of energy subjects: 'O $\pi \alpha \theta \omega ́ v, \mu \alpha \theta \omega ́ v ! '$}

Observing the challenges faced by the new energy poor over different periods of time revealed some of the wider temporal dynamics and rhythms (Walker, 2014) associated with material deprivation. It also pointed to the creative and pro-active ways in which households confronted the austerity regime, which at the same time has started to turn them into active political-infrastructural subjects.

The initial household interviews made it clear that initial responses to the economic crisis involved strategies and tactics that were already familiar and had been used in the past. However, the ensuing winter interviews indicated a number of unexpected and often innovative changes. This supports Simon's (2001, page 2) chronology of how people who are faced by crisis and uncertainty develop specific timeframes of action, in which the time of protracted waiting where they do not know precisely what 
they are dealing with tends to be replaced with 'fighting, dealing, and giving'. In Thessaloniki, many households had developed new skills and tactics, allowing for the more efficient and effective use of energy in the home. They had also gained knowledge about alternative ways of mobilizing the existing infrastructures and resources of their residential environment. Some of them mentioned the ancient Greek saying 'O $\pi \alpha \theta \omega ́ v, \mu \alpha \theta \omega ́ v$ !', which means that a person that undergoes some form of hardship subsequently learns their lesson and eventually turns the misfortune into new skills. This highlights the importance of ephemeral experimentation as a way of assessing the efficacy people's efforts (Simone, 2001).

Marina and Odysseas claimed that their ability to deal with the economic crisis had been constantly improving:

'It is true that we learnt to economise on energy from past experience and this is why were able to cope financially this winter' (H12, winter interview).

Variety of 'do-it-yourself' solutions have rendered innovative socio-technical assemblages (McFarlane, 2012). Damian proudly explained his inventions in their home energy system:

'I have installed a device in our fireplace which is like a fan and now we get a temperature around 23-24 degrees in our house' (H15, winter interview).

Energy poverty research often explicitly focuses on domestic energy coping strategies, without considering challenges related to mobility and transport 
(Middlemiss and Gillard, 2015; Petrova et al., 2013). Among the interviewed households, the crisis did not always result in reductions in energy demand, because people made trade-offs in different domains. They limited their use of private cars and transport more generally. Instead, informal and alternative neoliberal practices developed in the form of 'uber'-type modes of transport - including car-sharing primarily among households from peri-urban areas. In other contexts, such practices tend to be accompanied by the informalization of space, labour and governance (McFarlane, 2012). It can thus be argued that austerity has created a wider space for informal and shared networking, primarily in relation to activities that take place at the rural-urban interface (Roy, 2005). Although such collaborative engagements have an ephemeral, flexible, and tentative character, they can also provide a degree of security and opportunity (Simone, 2001).

The use of various collective practices in non-energy domains has also been essential in terms of dealing with energy poverty. For Adonia and Alekos' young family, help from their neighbours was invaluable:

Adonia: Our relatives live outside Thessaloniki, we have two small children and we both work outside the city. We have very good relations with our neighbours next door. So whenever I need help with my little ones I can count on them. And this is one of the main reasons why we decided not to move' (H4, summer interview).

The state's decreased ability to provide effective energy services to the population has not prevented it from organizing and managing people's everyday lives. This have 
involved the 'internaliation' of self-discipline via modes of self-control that always serve to regulate individual precariousness (Vasudevan, 2015; Petrova, 2017a). Thus, a number of households reported being aware of the environmental consequences of using fuelwood, especially in relation to air pollution. They attempted to change such practices to the detriment of their own welfare. Damara found it important to emphasize the environmentally-conscious behavior of her household:

'We buy good quality fuelwood. I am saying this in connection to the increasing levels of smog' (H2, winter interview).

Although all of the interviewed households acknowledged the need and pressure to use energy in an environmentally friendly way, many of them were frustrated by the inability to achieve this due to the economic crisis:

'So I would have liked a house that would be humidity free, as eco-friendly as possible, and yes, I would have liked to use all these forms of green energy. I just do not think that I will ever be able to obtain that' (Adonia, H4, winter interview).

It has been argued that the promotion of informal collective action as a bottom up 'solution' to austerity has removed more systemic debates about the issue from public fora (via 'people are resilient and they can cope' explanations) while depoliticizing the process of finding solutions (Evans and Reid, 2014). With regard to electricity, Wood (2016, page 175) has claimed that 'where electricity exists, the experience of no electricity is almost immediately a political one'. Traditionally, this failure of the 
state to provide adequate energy services in the home has been framed as 'a breach of public trust' (Wood, 2016, page 175). But under regimes such as the one that currently exists in Greece, the responsibility of the state as a key energy regulator and provider is shaped by the economic and financial specificities of austerity memoranda. Thus, the performativitities of state political power are shifted from the national scale to the vague international space of negotiation. Consequently, the national government's responsibilities as a key energy regulator and provider have been muted too.

In the energy context, it can be argued that the austerity regime has 'conducted the conduct' of people in manner that creates new spaces of energy vulnerabilities and inequalities, while generating feelings of frustration and anxiety in the making of environmental subjects (Boyd et al., 2014b). Austerity can thus be seen a key factor in the production of what a specific kind of energy subjectivity (Gailing and Moss, 2016) in the case of the new poor. This subjectivity is lies at the fulcrum of the environmental and infrastructural behaviours conditioned by the austerity regime, on the one hand, and the pro-active strategies that households adopt in order to overcome the lack of adequate energy services in the home, on the other.

\section{(A)political energy: everyday resistance to austerity}

The Greek crisis has been mostly understood via conspicuous collective political protests such as the ones at Syntagma Square in 2011 (Kaika and Karaliotas, 2014). Yet the individual motives of the people who took part in the collective resistance 
against the political-economic hegemony of the 'Quartet' and associated debt agreements have not been researched in detail. I thus now turn to a discussion of energy consumption patterns that can be seen as part of 'everyday resistance' (Johansson and Vinthagen, 2014; Scott, 1990) to the austerity regime in Greece. Everyday resistance in this context is understood as the manner in which 'everyday actors strategically subvert, appropriate, and contest hegemonic spaces and the dominant relations they stand for' (Rose, 2002, page 383). In general, everyday resistance strategies can be either intentional or unintentional, depending on whether they are motivated by a conscious ideological and political agenda (ibid).

Many Greek households contested the aforementioned property tax charge by refusing to pay electricity bills. Some also declined to make electricity payments for rental properties that do not bring any revenue - an unsurprising decision in light of the fact that land and housing lost between 20 and 35 per cent of their commercial value since the start of the crisis (Hadjimichalis, 2014). Electricity bill non-payment has been perceived as a signifier of intentional resistance, despite failing to decrease the overall disconnection rate. This resistance, we would argue, is directed against the notion of austerity as an ideology based on a 'moral economy' that recruits ethical subjects to come together and solve the problem (Newman, 2017)

The constant limitations on energy services - especially space heating and cooling, also made people feel imprisoned in their own homes. One of the ways in which they managed to overcome the inadequate thermal comfort was the increased frequency of visits to houses of friends and relatives. This was clearly pointed out by Dosia: 
'We stay in our apartment during the week and on the weekends we go to our village. When you start paying for natural gas and other bills you remember to visit your mother more often [laughter]' (H10, summer interview).

Access to alternative energy services has often been infrastructurally limited (e.g. due to the lack of natural gas network coverage), polluting (such as in the case of burning fuelwood) or burdened with taxes (particularly electricity). When asked about the new energy prices in the context of air pollution regulations, Damara (H2) expressed her anger with austerity-related restrictions and prescriptions on how people should live their lives:

'For the time being, we are looking after our comfort. After having stopped using the radiator, I feel entitled to spend as much electricity or fuelwood as I like!' (H2, winter interview)

For her, this mundane form of disobedience gave her power that challenged the controls imposed by austerity. Despite being embedded in everyday life, such forms of resistance may significantly change the ways in which energy is perceived and used. What is more, they challenge established practices linked to the use of traditional energy appliances:

'I have neither the time nor the patience to cook with the fuelwood stove' (Damara, H2, winter interview). 
Almost all of the households involved in my study questioned the rising prices of domestic heating oil. Daphne felt that the cost of this fuel was patently unjust. Her household decided to rely on electricity for space heating and cooling:

\begin{abstract}
'Last year we stopped using petroleum radiators in our house when we learned that the price of petrol went from under 1 to 1.3 Euros ... and to, be honest, I was quite angry at them changing the prices at their own will and we thought 'F*** off! We are not paying for this! It's crazy!' (H9, summer interview).
\end{abstract}

The rejection of 'archaic' technologies that were used in similar times of crisis reflects the struggle of the 'new energy poor' to hold on 'modern' means that belonged to them before the crisis. It is also a protest against the broader context of austerity and austerity-ridden governmentality that requires sustainability and resilience (Kaika, 2017; Petrova, 2017b).

Damara's daughter Kora (H2) believed that energy policy contestations - especially the revolt against higher oil prices - could have been transformed into a more coherent corpus of collective political resistance:

'It is a form of protest not to use heating oil, I thought that if done collectively it would have acted as a form of pressure towards the government, but obviously it has not' (H2, summer interview).

Much of the relevant literature sees resistance as a means for subaltern classes to contest political orthodoxies (Rose, 2002). But in this case, the households did not 
belong to social groups that have been conventionally seen as marginalized - because many of them were formerly part of the middle class. As such, they cannot be easily classified within established socio-political categories. Even if counter-austerity struggles should not be romanticized, their transformative potential deserves to be considered and included in progressively-minded attempts to promote societal empowerment from below.

\section{Conclusions}

This paper has examined the everyday experiences of and resistance to austerity as experienced by Greek households. Inspired by Newman (2017), it has scrutinized austerity as a policy, ideology and governmentality. We have focused on the emergence of the 'new energy poor' - a diverse socio-demographic group of people, who have been rendered through austerity politics, and yet have not received sufficient academic attention. As such, the paper contributes to debates on environmentality (Boyd et al., 2014a) and the politics of informality (Boudreau and Davis, 2017) by situating the agency of the 'new energy poor'. It encompasses and goes beyond Simone's (2016) description on social experimentation by showing that the 'new energy poor' in Greece have developed multiple complex socio-technical energy use tactics that are both ephemeral and in flux - they possess the potential to evolve, expend and readjust. These observed austerity-ridden tactics are constitutive of and constituted by not only in social (Simone, 2016), but material and infrastructural experimentations too. Although they seemingly lack the empowering capacity to make a lasting impact, they should be seen as integral to a potentially 
progressive politics of adaptation and experimentation in the 'age of austerity' (Peck, 2012) where the capitalist system is undergoing dramatic shifts (Thieme, 2017).

The paper has also demonstrated that while energy poverty exists among urban and peri-urban households alike, it is experienced and resisted in different ways. Nevertheless, for both the urban and peri-urban 'new energy poor' the importance of the urban-rural interface is a locus where dynamic energy related experimentation tends to occur (Roy, 2005). Thus, we would emphasise the need for further investigations of this dynamic, especially in light of its relative absence from both energy poverty studies and research on austerity.

In a sense, the austerity regime has rendered the new energy poor in Greece both vulnerable and governable; vulnerable because new taxes, higher prices, lower incomes and inadequate socio-technical support have reinforced broader processes of precarization (Lorey, 2015) to increase the sensitivity to, and severity of, domestic energy deprivation; and governable because people's energy needs and practices have been used as a tool for the construction of crisis and as a mechanism for regulating everyday life (Agrawal, 2005). Discourses of environmentality and the 'fear of power cuts' have been socially engineered with the intention to produce 'responsible' citizens who respect norms and practices essential for the (re)configuration of postcrisis capitalism (Petrova, 2017b). This calls for more substantial engagements with local agencies and acts of empowerment as 'technologies of self' (Singh, 2013). The complementarity of such aspects with the environmentality framework means that they can generate spatially- and politically-sensitive understandings of infrastructural inequality more generally. 


\section{References}

Agrawal, A. (2005) 'Environmentality: Community, Intimate Government, and the Making of Environmental Subjects in Kumaon, India', Current Anthropology, 46(2), pp. 161-190. doi: 10.1086/427122.

Alejos, E. and Paz, M. (2013) 'An austerity-driven energy reform', Spanish Economic and Financial Outlook, 2, pp. 51-60.

Arampatzi, A. (2017) 'Contentious spatialities in an era of austerity: Everyday politics and "struggle communities" in Athens, Greece', Political Geography, 60(Supplement C), pp. 47-56. doi: 10.1016/j.polgeo.2017.03.010.

Baxter, J. and Eyles, J. (1997) 'Evaluating Qualitative Research in Social Geography: Establishing "Rigour" in Interview Analysis', Transactions of the Institute of British Geographers, 22(4), pp. 505-525. doi: 10.1111/j.0020-2754.1997.00505.x.

Boudreau, J.-A. and Davis, D. E. (2017) 'Introduction: A processual approach to informalization', Current Sociology, 65(2), pp. 151-166. doi:

$10.1177 / 0011392116657286$.

Bouzarovski, S. (2014) 'Energy poverty in the European Union: landscapes of vulnerability', Wiley Interdisciplinary Reviews: Energy and Environment, 3(3), pp. 276-289. doi: 10.1002/wene.89.

Bouzarovski, S. and Petrova, S. (2015) 'A global perspective on domestic energy deprivation: Overcoming the energy poverty-fuel poverty binary', Energy Research \& Social Science, 10, pp. 31-40.

Bouzarovski, S. and Tirado Herrero, S. (2015) 'The energy divide: Integrating energy transitions, regional inequalities and poverty trends in the European Union', European Urban and Regional Studies, 24, pp. 69-86.

Boyd, E. et al. (2014a) 'Environmentalities of urban climate governance in Maputo, Mozambique', Global Environmental Change, 26, pp. 140-151. doi: 10.1016/j.gloenvcha.2014.03.012.

Boyd, E. et al. (2014b) 'Environmentalities of urban climate governance in Maputo, Mozambique', Global Environmental Change, 26, pp. 140-151. doi: 10.1016/j.gloenvcha.2014.03.012.

Bristow, G. and Healy, A. (2015) 'Crisis response, choice and resilience: insights from complexity thinking', Cambridge Journal of Regions, Economy and Society, p. rsv002. doi: 10.1093/cjres/rsv002.

Brown, W. (2016) 'Sacrificial Citizenship: Neoliberalism, Human Capital, and Austerity Politics’, Constellations, 23(1), pp. 3-14. doi: 10.1111/1467-8675.12166. 
Dąbrowski, M. (2015) “Doing more with less" or "doing less with less"? Assessing EU cohesion policy's financial instruments for urban development', Regional Studies, Regional Science, 2(1), pp. 73-96. doi: 10.1080/21681376.2014.999107.

Dagoumas, A. and Kitsios, F. (2014) 'Assessing the impact of the economic crisis on energy poverty in Greece', Sustainable Cities and Society, 13, pp. 267-278. doi: 10.1016/j.scs.2014.02.004.

De Laurentis, C., Eames, M. and Hunt, M. (2016) 'Retrofitting the built environment "to save" energy: Arbed, the emergence of a distinctive sustainability transition pathway in Wales', Environment and Planning C: Government and Policy, p. Doi: $10.1177 / 0263774 X 16648332$.

Elwood, S. A. and Martin, D. G. (2000) “"Placing” Interviews: Location and Scales of Power in Qualitative Research', The Professional Geographer, 52(4), pp. 649-657. doi: 10.1111/0033-0124.00253.

Evans, B. and Reid, J. (2014) Resilient Life: The Art of Living Dangerously. New York, NY: Polity Press.

Foucault, M. (1991) 'Governmentality', in Burchell, G., Gordon, C., and Miller, P. (eds) The Foucault effect: studies in governmentality. London: Harvester Wheatsheaf, pp. 87-104.

Frey, J. H. and Fontana, A. (1991) 'The group interview in social research', The Social Science Journal, 28(2), pp. 175-187. doi: 10.1016/0362-3319(91)90003-M.

Gailing, L. and Moss, T. (eds) (2016) Conceptualizing Germany's Energy Transition. London: Palgrave Macmillan UK.

Hadjimichalis, C. (2011) 'Uneven geographical development and socio-spatial justice and solidarity: European regions after the 2009 financial crisis', European Urban and Regional Studies, 18(3), pp. 254-274. doi: 10.1177/0969776411404873.

Hadjimichalis, C. (2014) 'Crisis and land dispossession in Greece as part of the global "land fever", City, 18(4-5), pp. 502-508. doi: 10.1080/13604813.2014.939470.

Hall, S. M. (2015) 'Everyday Ethics of Consumption in the Austere City', Geography Compass, 9(3), pp. 140-151. doi: 10.1111/gec3.12202.

Healy, J. D. (2004) Housing, fuel poverty, and health: a pan-European analysis. Aldershot, England; Burlington, VT: Ashgate Pub.

Ioakimidis, V., Santos, C. C. and Herrero, I. M. (2014) 'Reconceptualizing social work in times of crisis: An examination of the cases of Greece, Spain and Portugal', International Social Work, 57(4), pp. 285-300. doi: 10.1177/0020872814524967.

Johansson, A. and Vinthagen, S. (2014) 'Dimensions of Everyday Resistance: An Analytical Framework', Critical Sociology, p. 0896920514524604 . doi:

$10.1177 / 0896920514524604$. 
Jupp, E. (2016) 'Families, policy and place in times of austerity', Area, p. n/a-n/a. doi: 10.1111/area.12263.

Kaika, M. (2012) 'The economic crisis seen from the everyday', City, 16(4), pp. 422430. doi: 10.1080/13604813.2012.696943.

Kaika, M. (2017) “"Don’t call me resilient again!”: the New Urban Agenda as immunology ... or ... what happens when communities refuse to be vaccinated with "smart cities" and indicators', Environment and Urbanization, 29(1), pp. 89-102. doi: $10.1177 / 0956247816684763$.

Kaika, M. and Karaliotas, L. (2014) 'The spatialization of democratic politics: Insights from Indignant Squares', European Urban and Regional Studies, p. 0969776414528928. doi: 10.1177/0969776414528928.

Karaliotas, L. (2017) 'Performing neoliberalization through urban infrastructure: Twenty years of privatization policies around Thessaloniki's port', Environment and Planning A: Economy and Space, 49(7), pp. 1556-1574.

Katsoulakos, N. (2011) 'Combating energy poverty in mountainous areas through energy-saving interventions', Mountain Research and Development, 31, pp. 284-292.

Katsoulakos, N. M. and Kaliampakos, D. C. (2014) 'What is the impact of altitude on energy demand? A step towards developing specialized energy policy for mountainous areas', Energy Policy, 71, pp. 130-138. doi: 10.1016/j.enpol.2014.04.003.

Knight, D. M. (2014) A Critical Perspective on Economy, Modernity and Temporality in Contemporary Greece through the Prism of Energy Practice. London: London School of Economics and Political Science.

Leontidou, L. et al. (2007) 'Infrastructure related urban sprawl: Mega-events and hybrid peri-urban landscapes in southern Europe', in Couch, C., Leontidou, L., and Petschel-Held, G. (eds) Urban Sprawl in Europe. Oxford: Blackwell, pp. 71-98.

Lorey, I. (2015) State of Insecurity: Government of the Precarious. Verso.

Maloutas, T. and Karadimitriou, N. (2001) 'Vertical Social Differentiation in Athens: Alternative or Complement to Community Segregation?', International Journal of Urban and Regional Research, 25(4), pp. 699-716. doi: 10.1111/1468-2427.00340.

Mavroudeas, S. (2014) Greek Capitalism in Crisis: Marxist Analyses. Routledge.

McFarlane, C. (2012) 'Rethinking Informality: Politics, Crisis, and the City', Planning Theory \& Practice, 13(1), pp. 89-108. doi:

10.1080/14649357.2012.649951.

Michalopoulos, S. (2015) Athens opposes EU energy strategy, blocks privatisations. Available at http://www.euractiv.com/section/energy/news/athens-opposes-euenergy-strategy-blocks-privatisations/: Accessed 11 th July 2016. 
Middlemiss, L. and Gillard, R. (2015) 'Fuel poverty from the bottom-up:

Characterising household energy vulnerability through the lived experience of the fuel poor', Energy Research \& Social Science, 6, pp. 146-154.

Mouzelis, N. P. (1979) Modern Greece: Facets of Underdevelopment. Springer.

Newman, J. (2017) 'Re-gendering governance in time of austerity: Dilemmas of feminist research, theory and politics', in Hudson, C. M., Rönnblom, M., and Teghtsoonian, K. (eds) Gender, Governance and Feminist Analysis: Missing in Action? New York: Taylor \& Francis, pp. 21-39.

Papada, L. and Kaliampakos, D. (2016) 'Measuring energy poverty in Greece', Energy Policy, 94, pp. 157-165. doi: 10.1016/j.enpol.2016.04.004.

Paravantis, J. A. and Santamouris, M. (2014) 'Fuel poverty and indoor temperature clusters of low income households in Athens, Greece', in The 5th International Conference on Information, Intelligence, Systems and Applications, IISA 2014. The 5th International Conference on Information, Intelligence, Systems and Applications, IISA 2014, pp. 294-299. doi: 10.1109/IISA.2014.6878818.

Peck, J. (2012) 'Austerity urbanism', City, 16(6), pp. 626-655. doi: 10.1080/13604813.2012.734071.

Petrova, S. et al. (2013) 'Perceptions of thermal comfort and housing quality: exploring the microgeographies of energy poverty in Stakhanov, Ukraine', Environment and Planning A, 45(5), pp. 1240 - 1257.

Petrova, S. (2017a) 'Encountering energy precarity: geographies of fuel poverty among young adults in the UK', Transactions of the Institute of British Geographers, p. http://onlinelibrary.wiley.com/doi/10.1111/tran.12196/abstract. doi:

$10.1111 / \operatorname{tran} .12196$.

Petrova, S. (2017b) 'Illuminating austerity: Lighting poverty as an agent and signifier of the Greek crisis', European Urban and Regional Studies, Available at: http://dx.doi.org/10.1177/0969776417720250.

Pollio, A. (2016) 'Technologies of austerity urbanism: the "smart city" agenda in Italy (2011-2013)', Urban Geography, 37(4), pp. 514-534. doi:

10.1080/02723638.2015.1118991.

Poulantzas, N. (1977) 'The new petty bourgeoisie', in Hunt, A. (ed.) Class and Class Structure. London: Lawrence \& Wishart, pp. 113-124.

Pye, S. et al. (2015) Energy poverty and vulnerable consumers in the energy sector across the EU: analysis of policies and measures. Policy Report 2. INSIGHT_E.

Rose, M. (2002) 'The Seductions of Resistance: Power, Politics, and a Performative Style of Systems', Environment and Planning D: Society and Space, 20(4), pp. 383400. doi: $10.1068 / \mathrm{d} 262 \mathrm{t}$. 
Roy, A. (2005) 'Urban Informality: Toward an Epistemology of Planning', Journal of the American Planning Association, 71(2), pp. 147-158. doi:

10.1080/01944360508976689.

Saffari, A. et al. (2013) 'Increased Biomass Burning Due to the Economic Crisis in Greece and Its Adverse Impact on Wintertime Air Quality in Thessaloniki', Environmental Science \& Technology, 47(23), pp. 13313-13320. doi: 10.1021/es403847h.

Santamouris, M. et al. (2014) 'Freezing the poor-Indoor environmental quality in low and very low income households during the winter period in Athens', Energy and Buildings, 70, pp. 61-70. doi: 10.1016/j.enbuild.2013.11.074.

Santamouris, M. and Kolokotsa, D. (2015) 'On the impact of urban overheating and extreme climatic conditions on housing, energy, comfort and environmental quality of vulnerable population in Europe', Energy and Buildings. (Renewable Energy Sources and Healthy Buildings), 98, pp. 125-133. doi: 10.1016/j.enbuild.2014.08.050.

Scott, J. C. (1990) Domination and the Arts of Resistance: Hidden Transcripts. Yale University Press.

Sideri, E. (2016) 'Mobility in Thessaloniki: The Greek economic crisis and the transformation of mobility', in Shortell, T. and Brown, E. (eds) Walking in the European City: Quotidian Mobility and Urban Ethnography. London and New York: Routledge.

Simone, A. (2001) 'Straddling the Divides: Remaking Associational Life in the Informal African City', International Journal of Urban and Regional Research, 25(1), pp. 102-117. doi: 10.1111/1468-2427.00300.

Simone, A. (2016) 'City of Potentialities: An Introduction', Theory, Culture \& Society, 33(7-8), pp. 5-29. doi: 10.1177/0263276416666915.

Singh, N. M. (2013) 'The affective labor of growing forests and the becoming of environmental subjects: Rethinking environmentality in Odisha, India', Geoforum, 47, pp. 189-198. doi: 10.1016/j.geoforum.2013.01.010.

Sweeney, S. (2015) Energy Democracy in Greece: SYRIZA's Program and Transition to Renewable Power. Available at: http://www.rosalux.eu/publications/energydemocracy-in-greece/ (Accessed: 10 May 2016).

Thieme, T. A. (2017) 'The hustle economy: Informality, uncertainty and the geographies of getting by’, Progress in Human Geography, p. 0309132517690039. doi: $10.1177 / 0309132517690039$.

Vaiou, D. (2014) 'Tracing aspects of the Greek crisis in Athens: Putting women in the picture', European Urban and Regional Studies, p. 0969776414523802. doi: $10.1177 / 0969776414523802$.

Valentine, G. (1999) 'Doing household research: interviewing couples together and apart', Area, 31(1), pp. 67-74. doi: 10.1111/j.1475-4762.1999.tb00172.x. 
Valentine, G. (2008) 'The Ties That Bind: Towards Geographies of Intimacy', Geography Compass, 2(6), pp. 2097-2110. doi: 10.1111/j.1749-8198.2008.00158.x.

Vasudevan, A. (2015) 'The makeshift city Towards a global geography of squatting', Progress in Human Geography, 39(3), pp. 338-359. doi:

10.1177/0309132514531471.

Walker, G. (2014) 'The dynamics of energy demand: Change, rhythm and synchronicity', Energy Research \& Social Science, 1, pp. 49-55. doi:

10.1016/j.erss.2014.03.012.

Wood, D. (2016) 'Electric activism: Analysis, alliances, and interventions', Economic Anthropology, 3(1), pp. 174-185. doi: 10.1002/sea2.12053.

World Health Organization Regional Office for Europe (2007) Housing, Energy and Thermal Comfort. A review of 10 countries within the WHO European Region.

Copenhagen: WHO Regional Office for Europe. 